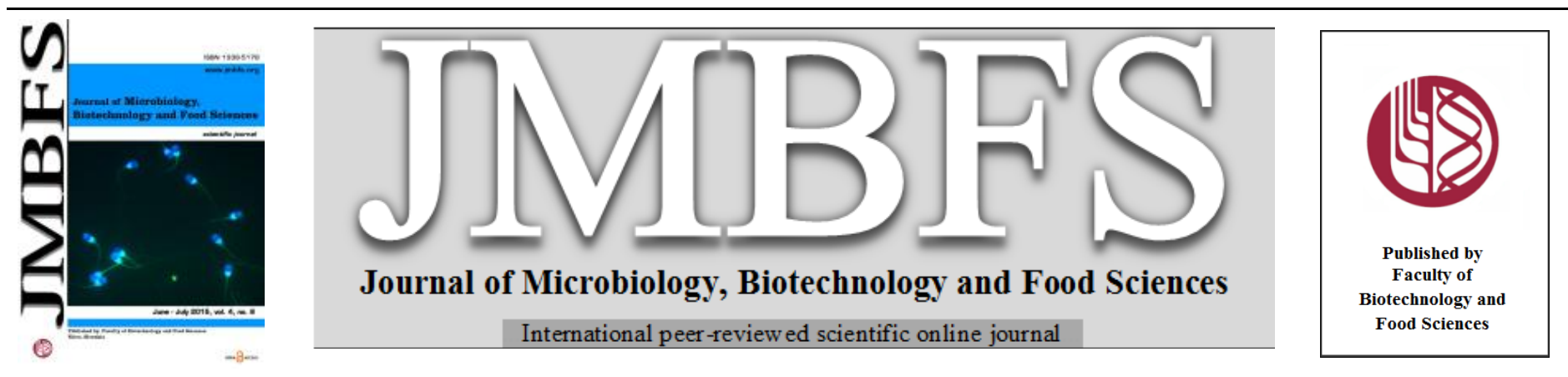

\title{
EFFECTS OF ARTICHOKE (CYNARA SCOLYMUS L.) EXTRACT ADDITION ON MICROBIOLOGICAL AND PHYSICO-CHEMICAL PROPERTIES OF PROBIOTIC YOGURT
}

\author{
Jalal Ehsani ${ }^{1 *}$, Amir Mohammad Mortazavian ${ }^{2}$, Morteza Khomeiri $^{3}$ and Azim Ghasem Nejad ${ }^{4}$ \\ Address(es): Jalal Ehsani, \\ ${ }^{1}$ Ferdowsi University of Mashhad, Department of Food Hygiene, Mashhad, Iran, Phone Number: +98-17-32174323, P.O. Box: 9177948974. \\ ${ }^{2}$ Shahid Beheshti University of Medical Sciences, Department of Food Science and Nutrition, Tehran, Iran. \\ ${ }^{3}$ GorganUniversity of Agricultural Sciences and Natural Resources, Department of Food Science and Technology, Gorgan, Iran. \\ ${ }^{4}$ GorganUniversity of Agricultural Sciences and Natural Resources, Department of Horticultural Science, Gorgan, Iran.
}

*Corresponding author: Jalal.Ehsani@gmail.com

doi: 10.15414/jmbfs.2015.4.6.536-541

\section{ARTICLE INFO}

Received 25. 2. 2015

Revised 26. 3. 2015

Accepted 30. 3. 2015

Published 1. 6. 2015

Regular article

open $\partial_{\text {ACCESS }}$

\begin{abstract}
In this study, the effects of addition of artichoke (Cynara scolymus L.) leaf extract into yogurt ( 0 or $0.5 \%$ ) on biochemical parameters $(\mathrm{pH}$, titrable acidity) and the viability of probiotic bacteria (Lactobacillus acidophilus LA-5, Bifidobacterium lactis BB-12) during fermentation and over 28 days of refrigerated storage $\left(4^{\circ} \mathrm{C}\right)$ were investigated. Moreover, the amounts of syneresis, total phenolic content, antioxidant activity and sensory attributes of yogurts at the end of fermentation were assessed. Yogurts contained the two yogurt bacteria (Streptococcus thermophilus and Lactobacillus delbrueckii ssp. bulgaricus: ABY) or only S. thermophilus (ABT) as adjunct culture to probiotics. Yogurts containing Cynara scolymus L. (ABT-C and ABY-C) had faster acidity increase, shorter incubation time and greater final titrable acidity than control yogurts (ABT and ABY). Also, yogurts containing Cynara scolymus L. had lower syneresis, higher total phenolic content and greater antioxidant activity. ABT-C yogurt had the ever greatest viability of probiotics. In case of samples sensory evaluation, generally, the highest total score was related to ABT yogurt whereas lowest total score belonged to ABT-C yogurt.
\end{abstract}

\section{INTRODUCTION}

Viability of probiotic microorganisms in the final product until the time of consumption is its most important qualitative parameter. Although there is no world-wide agreement on the minimum of viable probiotic cells per gram or milliliter of probiotic product until the time of consumption, generally, the values of $10^{6}$ and $10^{7}-10^{8} \mathrm{cfu} / \mathrm{mL}$ or $\mathrm{cfu} / \mathrm{g}$ have been accepted as the minimum and satisfactory levels, respectively. In Japan, the "Fermented Milks and Lactic Acid Bacteria Association" have standardized minimum of $10^{7} \mathrm{cfu} / \mathrm{mL}$ viable probiotic cells to be present in dairy products (Korbekandi et al., 2011; Tamime et al., 2005; Ahmadi et al., 2012 and Mortazavian et al., 2008). In Iran, National standard requires minimums of $10^{6} \mathrm{cfu} / \mathrm{mL}$ viable probiotic cells in yogurt (Anon, 2008a). It has also stated that probiotic products should be consumed regularly with an approximate amount of $100 \mathrm{~g} \mathrm{~d}^{-1}$ in order to deliver about $10^{9}$ viable cells into the intestine (Korbekandi et al., 2011).

Probiotic bacteria normally lose their viability during fermentation and storage period especially in fermented milks (Mortazavian et al., 2010; Shafiee $\boldsymbol{e t}$ al., 2010; Heydari et al., 2011; Mortazavian et al., 2007; Ahmadi et al., 2012; Mortazavian et al., 2006a; Mortazavian et al., 2006b; Mortazavian et al., 2007b and Mortazavian et al., 2011). Therefore, the high-priority attempt of probiotic industry has been increasing the survival and activity of probiotic microorganisms in dairy and non-dairy products, especially those with higher amounts of detrimental factors such as fermented foods. A common trend in fermented milks has been enrichment of milk with nutritious compounds that directly or indirectly increase the viability of probiotics (Korbekandi $\boldsymbol{e t}$ al., 2011).

The use of medicinal plants for treatment of different human diseases dates back to the primitive times. The Global Health Organization recently announced that $75-80 \%$ of the world's population treats themselves using natural drugs (Mocanu et al., 2010). Artichoke (Cynara scolymus $\mathrm{L}$.) is perennial, frost sensitive, thistle like plants with edible flower buds, which sprout from the terminal portion of the main stem and on lateral stems (Lopez-molina et al., 2005). Artichoke is not only popular for its pleasant bitter taste, but also is an interesting and widespread herbal medicine.
Artichoke leaf extract is widely used alone or in association with other herbs for embittering alcoholic and soft drinks and to prepare herbal teas or herbal medicinal products (Bonomi et al., 2001). Artichoke contains very little fat and high levels of minerals (potassium, sodium, phosphorus), vitamin C, fibre, inulin and polyphenols, hydroxycinnamates and flavones (Bianco et al., 1999 and Lattanzio et al., 1994). Inulin and polyphenols possesses hepatoprotective, anticarcinogenic and antioxidant activities (Gebhardt and Fausel, 1997; Jimenez-Escrig et al., 2003). Artichoke has been labelled as 'lifespan essential', since its consumption could decrease the risk of chronic illnesses such as diabetes, cancer and cardiovascular disease as well as cholesterol levels in the blood. It can also treat hepato-biliary dysfunction and digestive complaints such as loss of appetite, qualm and abdominal pain. Enhancement of detoxification reactions of the liver, cholagogue and choleretic activities have been also attributed to the ingestion of Artichoke (Holst and Williamson, 2008; Kraft 1997; Kirchhoff et al., 1994; Gebhardt and Fausel, 1997; Gebhardt 1995; Brown, 1998 and Kraft, 2001).Therefore, incorporation of Artichoke extracts into probiotic yogurt could highly enhance its functional properties. Furthermore, It has been hypothesized that some ingredients in mentioned extract might increase the viability of probiotics in products (Mocanu et al., 2011)

Considering what was mentioned, the aim of this study was to investigate the effects of artichoke (Cynara scolymus L.) leaf extract into yogurt on viability of Lactobacillus acidophilus LA-5, Bifidobacterium lactis BB-12 at the end of fermentation and during 28 days of refrigerated storage $\left(4^{\circ} \mathrm{C}\right)$.

\section{MATERIALS AND METHODS}

\section{Preparation of artichoke extract}

The artichoke samples were collected from the research stead of Gorgan University of Agricultural Sciences and Natural Resources and leaves were separated from the stem. The leaves washed and dried in an oven $\left(45^{\circ} \mathrm{C}, 24 \mathrm{~h}\right)$ and then were powdered using a laboratory mill (Mardani et al., 2011).

Artichoke extract was prepared according to the modified method by Mardani $\boldsymbol{e} t$ al. (2011). Artichoke leaves were soaked in $30 \%$ ethanol solvent. Then, $10 \mathrm{~g}$ 
powder was added to100 $\mathrm{mL}$ solvent and was mixed for $24 \mathrm{~h}$ at ambient temperature using a mechanical stirrer. Then, extract by typical filter paper was separated from solid part. Ethanolical extract was concentrated by rotary vacuum evaporator followed by the powdering of extract by freeze dryer device (Mardani et al., 2011).

\section{Starter culture}

Lyophilized pouches of commercial ABY culture (containing Lactobacillus acidophilus LA-5, Bifidobacterium lactis BB-12, Lactobacillus delbrueckii ssp. Bulgaricus and Streptococcus thermophilus) and ABT culture (containing $L$. acidophilus LA-5, B. lactis BB-12 and S. thermophilus) were supplied by ChrHansen (Horsholm, Denmark). The cultures were maintained according to manufacturer's instructions at $-18^{\circ} \mathrm{C}$ until used

\section{Preparation of yogurt samples}

Four yogurt treatments obtained from two types of formulations: $A B Y$ (Lactobacillus acidophilus LA-5, Bifidobacterium lactis BB-12, and yogur bacteria) and ABT (Lactobacillus acidophilus LA-5, Bifidobacterium lactis BB 12, and Streptococcus thermophilus) plus artichoke extract (0 or $0.5 \%)$ were produced using reconstituted skim milk powder and sterilized potable water Reconstituted milk samples were heat treated at $85^{\circ} \mathrm{C}-30 \mathrm{~min}$, then was cooled to $37^{\circ} \mathrm{C}$. After addition of inoculum and artichoke extract, fermentation was carried out at $37^{\circ} \mathrm{C}$ until $\mathrm{pH}$ reached $4.5 \pm 0.02$. Biochemical parameters including $\mathrm{pH}$ drop and acidity increase were monitored throughout the fermentation period These parameters were recorded every $30 \mathrm{~min}$. The final samples were cooled down and kept at $4{ }^{\circ} \mathrm{C}$ for 28 days. Viability of probiotic organisms, $\mathrm{pH}$, tota tritatable acidity, syneresis, total phenolic content and antioxidant activity were determined at the end of fermentation and within the storage period per 7-day intervals.

\section{Preparation of yogurt water extract for chemical analysis}

Yogurt sample $(10 \mathrm{~g})$ was mixed with $2.5 \mathrm{~mL}$ distilled water and the yogurt $\mathrm{pH}$ was adjusted to 4.0 using $0.1 \mathrm{M} \mathrm{HCl}$. The yogurt was then incubated at $45^{\circ} \mathrm{C}$ for $10 \mathrm{~min}$ followed by centrifugation $\left(5000 \mathrm{~g}, 10 \mathrm{~min}, 4^{\circ} \mathrm{C}\right)$. The supernatant was harvested and the $\mathrm{pH}$ was adjusted to 7.0 using $\mathrm{NaOH} 0.1 \mathrm{M}$. The neutralized supernatant was re-centrifuged $\left(5000 \mathrm{~g}, 10 \mathrm{~min}, 4^{\circ} \mathrm{C}\right)$ and the supernatant was harvested and stored in a $-20^{\circ} \mathrm{C}$ freezer until required for analysis (Amirdivani and Baba, 2011).

\section{Determination of total phenolic content of yogurt}

The total phenolic content of yogurt was determined by an assay modified from Shetty et al. (1995). Yogurt water extract $(1.0 \mathrm{~mL})$ was transferred into a tes tube and mixed with $1 \mathrm{~mL}$ of $95 \%$ ethanol and $5 \mathrm{~mL}$ of distilled water. To each sample, $0.5 \mathrm{~mL}$ of $50 \%$ (v/v) Folin-Ciocalteu reagent was added and mixed After $5 \mathrm{~min}, 1 \mathrm{~mL}$ of $5 \% \mathrm{Na}_{2} \mathrm{CO}_{3}$ was added and the reaction mixture was allowed to stand for $60 \mathrm{~min}$. The absorbance was read at $725 \mathrm{~nm}$ and the values were converted to total phenolics, expressed in milligrams equivalents of gallic acid per gram (GAE/g) sample. Gallic acid was used as standard (Apostolidis $\boldsymbol{e}$ al., 2007).

\section{Determination of antioxidant activity of yogurt}

Antioxidant activity of yogurt samples by 2, 2-diphenyl-1-picrylhydrazyl radical (DPPH) inhibition was determined by an assay modified from Shetty $\boldsymbol{e t}$ al. (1995). Yogurt water extract $(250 \mu \mathrm{l})$ was added into $3 \mathrm{ml}$ of $60 \mu \mathrm{M} \mathrm{DPPH}$ in ethanol. The decrease in absorbance was monitored at $517 \mathrm{~nm}$ until a constan reading was obtained. The readings were compared with the controls which contained distilled water $(250 \mu \mathrm{l})$ instead of yogurt water extract (Apostolidis et al., 2007)

The inhibition percentage was calculated as follows:

$$
\% \text { Inhibition }=\frac{\mathrm{A} \text { control }-\mathrm{A} \text { extract }}{\mathrm{A} \text { control }} \times 100
$$

\section{pH measurement and tritatable acidity}

$\mathrm{pH}$ values of the samples were measured at room temperature using a $\mathrm{pH}$ meter (Knick pH-meter 766 calimatic, Germany).

The titrable acidity was determined after mixing $10 \mathrm{~mL}$ of sample with $10 \mathrm{~mL}$ of distilled water and titrating with $0.1 \mathrm{~N} \mathrm{NaOH}$ using $0.5 \%$ phenolphthalein (Shafiee et al., 2010 and Ahmadi et al., 2012).

Various biochemical parameters were defined and determined as follows:

Mean $\mathrm{pH}$ drop rate $(\mathrm{mpH}-\mathrm{DR})=($ final $\mathrm{pH}$ value - initial $\mathrm{pH}$ value $) /$ incubation time [pH value/min] (Mortazavian et al., 2010 and Mortazavian et al., 2011)
Mean acidity increase rate $(\mathrm{mA}-\mathrm{IR})=($ final acidity value - initial acidity value $) /$ incubation time [Dornic degree/min] (Mortazavian et al., 2010 and Mortazavian et al., 2011).

Time to pH5.5 $\left(\mathrm{t}_{5.5}\right)$ : time from the start of incubation until reaching the $\mathrm{pH}$ of 5.5 [min].

Time range of maximum $\mathrm{pH}$ drop $\left(\mathrm{t}_{\mathrm{max}-\mathrm{pH}-\mathrm{D}}\right)$ : The 30 -min time interval during fermentation in which the greatest $\mathrm{pH}$ decline is observed [min-min]

\section{Syneresis measurement of yogurt}

$25 \mathrm{~g}$ of yogurt sample was weighed and placed on Whatman filter paper (No. 41) and on the funnel. Water out of the funnel was expressed after $120 \mathrm{~min}$ as syneresis (Tamime et al., 1996)

\section{Microbiological analysis of probiotics in yogurt}

MRS-bile agar medium (MRS agar by Merck, Darmstadt, Germany and bile by Sigma-Aldrich, Inc., Reyde, USA) was used for the selective enumeration of $L$. acidophilus and bifidobacteria in $\mathrm{ABY}$ and $\mathrm{ABT}$ culture compositions (Mortazavian et al., 2007 and Sohrabvandi $\boldsymbol{e t}$ al., 2012). The plates were incubated aerobically and anaerobically at $37^{\circ} \mathrm{C}$ for $72 \mathrm{~h}$. Anaerobic conditions were produced using the GasPac system (Merck, Darmstadt, Germany).

Viability proportion index (VPI) of probiotic microorganism at the end of fermentation was calculated as following (Mortazavian et al., 2010; Shafiee $\boldsymbol{e t}$ al., 2010 and Mortazavian et al., 2011)

VPI = Final cell population $(\mathrm{cfu} / \mathrm{mL}) /$ initial cell population $(\mathrm{cfu} / \mathrm{mL})$

\section{Sensory analysis of yogurt}

The treatments were analyzed and compared using a scoring method that was based on the Iran National Standard (Anon, 2008b). The sensory parameters were flavor, oral texture and mouthfeel, non-oral texture (pouring, stirring, and scoopability), and appearance (color, syneresis, and homogeneity with respect to the surface and texture). Each of these parameters was scored on a five-poin scale: 0 = inconsumable; 1 = unacceptable; 2 = acceptable; $3=$ satisfactory; and 4 $=$ excellent. The score for each sensory parameter was multiplied by the relevant coefficient, namely, 6 for flavor, 3.5 for oral texture and feel in the mouth, 2 for appearance, and 1 for non-oral texture.

\section{Statistical analysis}

Each treatment was produced four times and each experiment was performed in triplicate. Experiments were set up using a completely randomized design. Data were subjected to analysis of variance and comparison of the means was done using the ANOVA test from SPSS software at significance level of 0.05 .

\section{RESULTS AND DISCUSSION}

\section{Biochemical, chemical and physical characteristics of yogurts}

As is evident in Table 1, ABT-C yogurt (yogurt prepared by ABT culture containing $0.5 \%$ Cynara scolymus $\mathrm{L}$.) had the highest mean $\mathrm{pH}$ drop rate as well as the highest mean acidity increase rate $(p<0.05)$. In contrast, ABT yogurt (yogurt prepared by ABT culture, containing 0\% Cynara scolymus L.) had the lowest amounts for both mentioned parameters. ABY yogurt (yogurt prepared by ABY culture, containing 0\% Cynara scolymus L.) and ABY-C yogurt (yogurt prepared by $\mathrm{ABY}$ culture, containing 0.5\% Cynara scolymus L.) were intermediate in parameters. It seems that the addition of artichoke extract did not significantly affect buffering capacity of the product during fermentation, but stimulate the growth and/or activity of starter cells. The higher mean acidity increase rate in ABT-C yogurt could be mainly attributed to stimulating growth and/or activity of $S$. thermophilus, because ABT yogurt (without Cynara scolymus L.) showed the lowest mean $\mathrm{pH}$ drop and acidity increase rates. Therefore, addition of Cynara scolymus L. significantly stimulated the growth and/or activity of starter cultures especially $S$. thermophilus. These observations were consistent with those reported by Mocanu et al. (2010) for ABT culture composition. They found that during incubation period, for samples containing bilberry extract and mixture of bilberry and liquorice extracts, rate of acidity increase was higher than control sample. In other research, Mocanu et al. (2009) found that adding mixture of sea-buckthorn and liquorice extract to ABY yogurt was indicated the acidity increase rate higher than control sample.

The shortest incubation times were observed for ABT-C that had the highest mean $\mathrm{pH}$ drop and mean acidity increase rates. $\mathrm{ABY}$ yogurt rendered the longest incubation time, as expected. Time of maximum $\mathrm{pH}$ drop $\left(\mathrm{t}_{\text {max-pH-D }}\right)$ in ABY, ABY-C and ABT were 240-270 (min-min), whilst this time for the ABT-Cwas 180-210 (min-min) (Table 1), indicating that in ABT treatment containing $0.5 \%$ artichoke extract, during fermentation, were $60 \mathrm{~min}$ sooner in the peak of acidification and activity than others. The data related to the $\mathrm{pH}$ of maximum $\mathrm{pH}$ drop $\left(\mathrm{pH}_{\text {max-pH-D }}\right)$ also confirmed mentioned observation. For example, ABY-C yogurt showed 0.36 decline in $\mathrm{pH}(5.55-5.19)$ within the hours $240-270$ during 
fermentation, whilst this $\mathrm{pH}$ decline value was 0.29 (5.41-5.12) in within the hours 180-210 in ABY-C yogurt (Table 1). According to Table 1, the time to reach pH5.5 $\left(\mathrm{t}_{5.5}\right)$ for ABY, ABY-C, ABT and ABT-C yogurts were 250, 245, 258 and $168 \mathrm{~min}$, respectively. Amirdivani and Baba (2011) found that adding
O. basilicum, M. piperita and A. graveolens extracts within yogurt prepared by $S$. thermophilus, L. bulgaricus, L. acidophilus, and B. bifidom, significantly decreased incubation time and shortened the incubation time than control.

Table 1 Biochemical parameters, antioxidant activity, total phenol content and syneresis of treatments at the end of fermentation*

\begin{tabular}{|c|c|c|c|c|c|c|c|c|c|}
\hline \multirow[b]{2}{*}{ Treatment } & \multicolumn{8}{|c|}{ Parameters } & \multirow[b]{2}{*}{$\begin{array}{c}\text { Antioxidant } \\
\text { Activity } \\
\text { (\%inhibition) }\end{array}$} \\
\hline & $\begin{array}{c}\text { mpH_DR } \\
(\mathrm{pH} / \mathrm{min})^{* *}\end{array}$ & $\begin{array}{c}\text { MA_IR } \\
\left(^{\circ}\right. \\
\text { D/min })\end{array}$ & $\begin{array}{c}\mathbf{t}_{5.5} \\
(\min \\
)\end{array}$ & $\begin{array}{c}\mathbf{t}_{\text {max-pH-D }} \\
(\min - \\
\text { min) }\end{array}$ & $\begin{array}{c}\mathbf{p H}_{\text {max-pH-D }} \\
(\mathrm{pH}-\mathrm{pH})\end{array}$ & $\begin{array}{c}\begin{array}{c}\text { Incubation } \\
\text { time }\end{array} \\
(\min )\end{array}$ & $\begin{array}{c}\text { Syneresis } \\
(\mathrm{g} / \mathbf{2 5 g})\end{array}$ & $\begin{array}{c}\text { Total Phenolic } \\
\text { Content } \\
\text { (mg gallic acid/g } \\
\text { sample) }\end{array}$ & \\
\hline ABY & $0.0040^{c}$ & $0.150^{c}$ & $250^{\mathrm{bc}}$ & $240-270$ & $5.57-5.25$ & $480^{c}$ & $12.76^{\mathrm{a}}$ & $58.56^{\mathrm{c}}$ & $6.87^{\mathrm{c}}$ \\
\hline ABY-C & $0.0045^{\mathrm{b}}$ & $0.155^{\mathrm{b}}$ & $245^{\mathrm{b}}$ & $240-270$ & $5.55-5.19$ & $470^{\mathrm{b}}$ & $12.42^{\mathrm{ab}}$ & $87.50^{\mathrm{a}}$ & $17.25^{\mathrm{a}}$ \\
\hline ABT & $0.0035^{\mathrm{d}}$ & $0.142^{\mathrm{d}}$ & $258^{\mathrm{c}}$ & $240-270$ & $5.60-5.39$ & $490^{\mathrm{d}}$ & $11.14^{\mathrm{c}}$ & $51.25^{\mathrm{d}}$ & $3.80^{\mathrm{d}}$ \\
\hline ABT-C & $0.0050^{\mathrm{a}}$ & $0.160^{\mathrm{a}}$ & $168^{\mathrm{a}}$ & $180-210$ & $5.41-5.12$ & $460^{\mathrm{a}}$ & $10.83^{\mathrm{d}}$ & $76.47^{b}$ & $15.50^{\mathrm{b}}$ \\
\hline
\end{tabular}

*Means in the same column shown with different letters are significantly different $(p<0.05)$.

$* * \mathrm{mpH}-\mathrm{DR}=$ mean $\mathrm{pH}$ drop rate, $\mathrm{mA}-\mathrm{IR}=$ mean acidity increase rate, $\mathrm{t}_{5.5}=$ time to $\mathrm{pH} 5.5, \mathrm{t}_{\mathrm{max}-\mathrm{pH}-\mathrm{D}}=$ time range of maximum $\mathrm{pH}$ drop,

$\mathrm{t}_{\mathrm{max}-\mathrm{A}-\mathrm{I}}=$ time range of maximum titrable acidity increase, $\mathrm{pH}_{\text {max-pH-D }}=\mathrm{pH}$ of maximum $\mathrm{pHdrop}$

Syneresis, separation of aqueous phase from continuous phase or gel network, is undesirable in yogurt production. This is common in low-fat yogurt. The use of compounds such as gelatin, pectin, starch and prebiotics has been suggested to reduce syneresis (Harte et al., 2005 and Amaya-Liano et al., 2008) Considering Table 1, adding artichoke extract into yogurt (both, ABT and ABY) decreased syneresis compared to controls. The lowest syneresis was observed for ABT-C yogurt. In contrast highest syneresis related to ABY yogurt. Probably, Inulin in artichoke extract (Adwan et al., 2007) that is a water-structuring agent, acted as a thickener and could form complexes (H-bridge formation) with the protein aggregates in the yogurt. Gustaw et al. (2011) found that addition of 1\% inulin, resistant starch and fructooligosaccharide (FOS) within ABT yogurt decreased the syneresis.

Considering Table 1, the greatest total phenolic content (TPC) in yogurts was found in ABY-C $(87.50 \mathrm{mg} \mathrm{GA} e q / \mathrm{g})$ and the lowest in those without plant extracts. Since ABY and ABT yogurts contains no plant extracts, the TPC values in $A B Y$ and $A B T$ yogurts reflected phenolic compounds related to milk components, especially milk proteins (Damin et al., 2009). The amino acid tyrosin for instance has a phenolic side chain suggested to give rise to the reading in TPC (Shah, 2000). It should be noted, that artichoke is a rich source of the polyphenol compounds, with mono- and di-caffeoylquinicacids and flavonoids
(Nichiforescu, 1970; Adzet and Puigmacia, 1985; Dranik et al., 1996 and Wagenbreth, 1996)

Considering Table 1, both herbal yogurts (ABY-C and ABT-C) had higher $(p<0.05)$ antioxidant activity than plain yogurts $(\mathrm{ABY}$ and $\mathrm{ABT})$ at the end of fermentation. The Highest antioxidant activity in yogurts was found in ABY-C $(17.25 \%)$ and the lowest in ABT $(3.80 \%)$. The higher antioxidant activity in ABY-C and ABT-C yogurts than in plain-yogurts (ABY and ABT) were most likely contributed by individual herbal phytochemical contents and as a result of microbial metabolic activities (Thompson et al., 2007). The antioxidant activity of artichoke has been reported by Gebhardt (1997).The observed effects of cynarin and caffeic acid (within artichoke) have been assigned to the antioxidant activity of these compounds. Also, Brown and Rice-Evans (1998) and Lattanzio et al. (1994) found that luteolin (within artichoke) is a strong antioxidant that protects low density lipoproteins from oxidation.

Viability of probiotic bacteria at the end of fermentation and during refrigerated storage

Table 2 shows viability of probiotic microorganisms as well as the viability proportion indexes (VPI) in different yogurts immediately after fermentation.

Table 2 Viability of probiotic microorganisms and the viability proportion index (VPI) in different treatments at the end of fermentation

\begin{tabular}{|c|c|c|c|c|c|c|c|c|c|}
\hline \multirow[b]{2}{*}{ Treatment } & \multicolumn{3}{|l|}{ cfu/mL) } & \multicolumn{3}{|c|}{$\begin{array}{c}\text { final population }\left(D_{0}\right) \\
(\log \mathrm{cfu} / \mathrm{mL})\end{array}$} & \multicolumn{3}{|c|}{ VPI } \\
\hline & $\mathbf{A}^{*}$ & $\bar{B}$ & $\mathbf{A}+\mathbf{B}$ & $\overline{\mathbf{A}}$ & B & $\overline{A+B}$ & $\bar{A}$ & $\bar{B}$ & $\overline{A+B}$ \\
\hline ABY & $7.57 \pm 0.06$ & $7.72 \pm 0.08$ & $7.95 \pm 0.04$ & $8.18 \pm 0.04$ & $8.22 \pm 0.07$ & $8.51 \pm 0.04$ & 4.11 & 3.19 & 3.57 \\
\hline ABY-C & $7.57 \pm 0.06$ & $7.72 \pm 0.08$ & $7.95 \pm 0.04$ & $8.42 \pm 0.07$ & $8.53 \pm 0.06$ & $8.79 \pm 0.01$ & 7.14 & 6.49 & 6.75 \\
\hline ABT & $6.29 \pm 0.03$ & $6.48 \pm 0.05$ & $6.7 \pm 0.09$ & $7.14 \pm 0.10$ & $7.24 \pm 0.05$ & $7.50 \pm 0.06$ & 7.15 & 5.74 & 6.29 \\
\hline ABT-C & $6.29 \pm 0.03$ & $6.48 \pm 0.05$ & $6.7 \pm 0.09$ & $7.47 \pm 0.12$ & $7.54 \pm 0.06$ & $7.81 \pm 0.09$ & 15.34 & 11.54 & 13.02 \\
\hline
\end{tabular}

$\mathrm{A}^{*}=$ L. acidophilus, $\mathrm{B}=$ bifidobacteria, $\mathrm{A}+\mathrm{B}=$ total probiotics

As represented from this Table, the viability of both probiotic bacteria $(L$. acidophilus LA-5 and B. lactis BB-12) were significantly and markedly greater in the treatments containing artichoke extract (ABY-C and ABT-C) than controls (ABY and $\mathrm{ABT}$ ). For instance according to Table 2, the final population of $L$. acidophilus (at the end of fermentation) in ABY-C was 7.14-fold of initial population, compared to 4.11-fold in ABY. The amounts for ABT-C and ABT were 15.34 and 7.15, respectively. As was evident, the viability of both probiotic bacteria in treatments without $L$. delbrueckii ssp.bulgaricus (ABT and ABT-C) was significantly and considerably greater than their related treatments contained mentioned yogurt bacteria (ABY and ABY-C), because it is well-known that $L$. delbrueckii ssp.bulgaricus can suppress probiotics (Mortazavian et al., 2006 and Mortazavian et al., 2007).

The positive effects of artichoke on viability of probiotics can be attributed to the reason that artichoke provide higher nutritious and stimulatory media for lactic acid bacteria and probiotic bacteria, and stimulate their growth and activity. From these substances, exopolysaccharide, adenine, hypoxanthine, free amino acids, and essential vitamins and minerals can be mentioned (Parada $\boldsymbol{e t}$ al., 1998; Zielke et al., 1978; Varga et al., 1999; Gibson and Roberfroid, 1995; Kurita, 1979; Shirota et al., 1964; Stengel, 1970 and Webb, 1982). Lutz et al. (2011) reported that artichoke contains proteins, carbohydrates and dietary fiber that could affect viability of probiotics. Also, Llorach et al. (2002) and Fratianni et al. (2007) announced that artichoke contains proteins, minerals, low amounts of lipids, dietary fiber and a high proportion of phenolics. Mocanu et al. (2011) found that adding mixture of rosehip and liquorice extract to $\mathrm{ABY}$ and $\mathrm{ABT}$ yogurt, increased viability of probiotic bacteria (LA-5 and BB-12) and highes viability of lactic acid bacteria were observed in ABT yogurt containing mixture of rosehip and liquorice extract. Table 3 shows the viability of probiotic microorganisms in different treatments during refrigerated storage. 
Table 3 Viability (log cfu/mL) of probiotic microorganisms in different treatments during refrigerated storage

\begin{tabular}{|c|c|c|c|c|c|c|c|c|c|c|c|c|}
\hline \multirow[b]{2}{*}{ Treatment } & \multicolumn{3}{|c|}{$\mathbf{D}_{7}$} & \multicolumn{3}{|c|}{$D_{14}$} & \multicolumn{2}{|r|}{$D_{21}$} & \multicolumn{4}{|c|}{$\mathbf{D}_{28}$} \\
\hline & $A^{*}$ & B & $A+B$ & A & B & $A+B$ & A & B & $A+B$ & A & B & $A+B$ \\
\hline ABY & $8.00 \pm 0.0$ & $8.02 \pm 0.03$ & $8.31 \pm 0.01$ & $7.51 \pm 0.56$ & $7.60 \pm 0.66$ & $8.04 \pm 0.46$ & $7.13 \pm 0.34$ & $7.14 \pm 0.14$ & $7.45 \pm 0.24$ & $6.86 \pm 0.26$ & $6.84 \pm 0.34$ & $7.18 \pm 0.24$ \\
\hline ABY-C & $8.39 \pm 0.0$ & $8.41 \pm 0.05$ & $8.71 \pm 0.03$ & $8.02 \pm 0.06$ & $8.01 \pm 0.05$ & $8.32 \pm 0.03$ & $7.68 \pm 0.07$ & $7.69 \pm 0.45$ & $8.01 \pm 0.28$ & $7.48 \pm 0.25$ & $7.46 \pm 0.08$ & $7.79 \pm 0.12$ \\
\hline ABT & $6.99 \pm 0.0$ & $7.01 \pm 0.09$ & $7.30 \pm 0.04$ & $6.73 \pm 0.29$ & $6.78 \pm 0.05$ & $7.07 \pm 0.10$ & $6.34 \pm 0.83$ & $6.36 \pm 0.50$ & $6.81 \pm 0.59$ & $6.03 \pm 0.06$ & $6.12 \pm 0.75$ & $6.48 \pm 0.35$ \\
\hline ABT-C & $7.39 \pm 0.4$ & $7.45 \pm 0.16$ & $7.76 \pm 0.27$ & $7.25 \pm 0.29$ & $7.29 \pm 0.12$ & $7.59 \pm 0.15$ & $6.95 \pm 0.10$ & $7.01 \pm 0.63$ & $7.36 \pm 0.24$ & $6.68 \pm 0.14$ & $6.74 \pm 0.44$ & $7.05 \pm 0.21$ \\
\hline
\end{tabular}

$\mathrm{A}^{*}=$ L. acidophilus, $\mathrm{B}=$ bifidobacteria, $\mathrm{A}+\mathrm{B}=$ total probiotics

Table 4 represents their relative viability proportion index (VPI) during this period. Itis notable that the viability of both probiotic bacteria were significantly greater in the treatments containing artichoke extract (ABY-C and ABT-C yogurts) compared to control (ABY and $\mathrm{ABT}$ yogurts) during storage period of
28 days. According to Table 4, viability proportion index (VPI) of probiotic bacteria in ABT yogurt was significantly higher than $\mathrm{ABY}$ yogurt during refrigerated storage.

Table 4 Viability proportion index (VPI) of probiotic bacteria during $28 \mathrm{~d}$ of storage at $4^{\circ} \mathrm{C}$, per 7 -day intervals (compared to the initial viable cell counts immediately after fermentation or the viable cell counts at the last days of each 7-day storage interval)

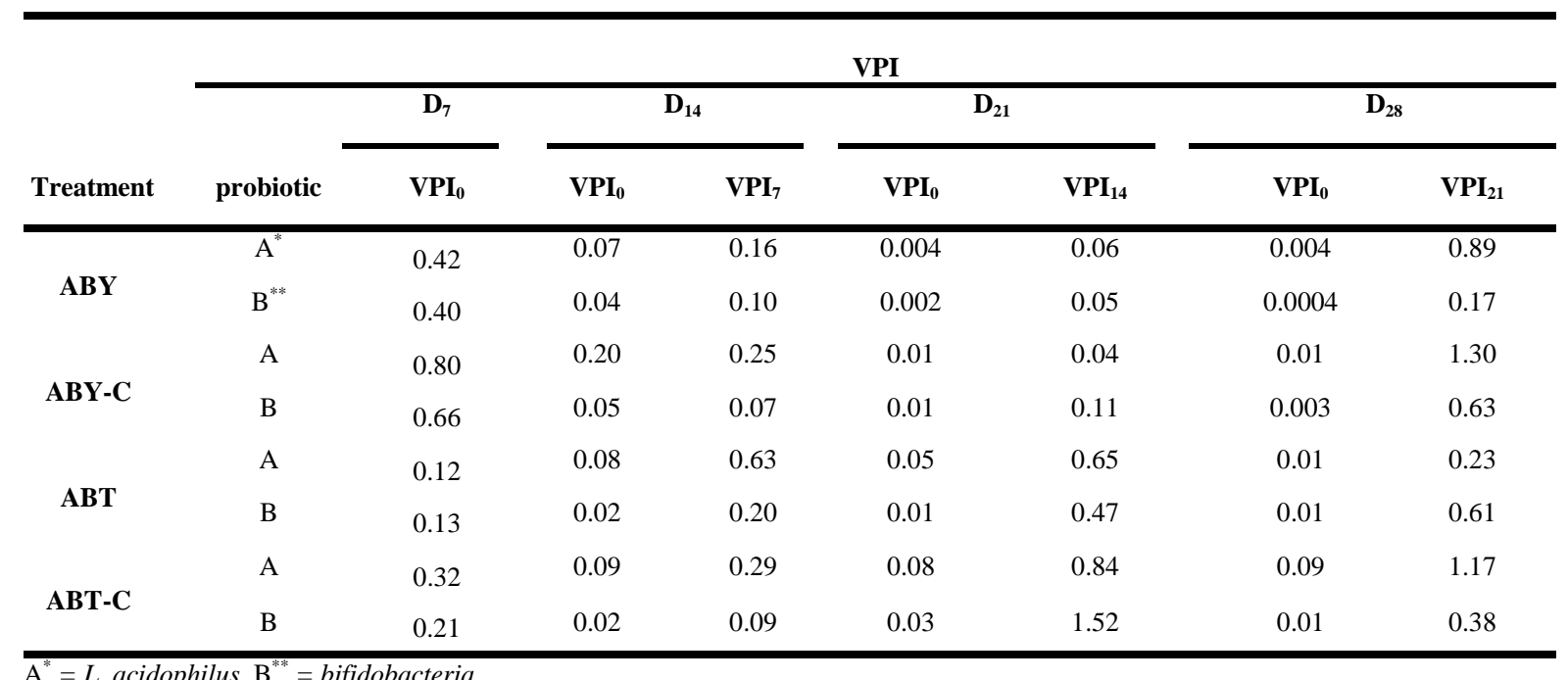

However, in ABT-C and ABY-C yogurts, the rate of probiotic reduction was very slower (ABT-C had the lowest reduction rate in viable count). A. platensissupplemented fermented ABT milk contained significantly higher $(p<0.05)$ levels of lactobacilli than the control during storage time (Kurita et al., 1979). Mocanu et al. (2010) were observed that highest number of probiotic bacteria at the end of refrigerate storage, belongs to $\mathrm{ABT}$ yogurt containing mixture of bilberry and liquorice extract compared to ABT yogurt.

Corresponding with Iranian national standard, viability of probiotic bacteria was greater than $10^{6} \mathrm{cfu} / \mathrm{mL}$ in all yogurts until the d 28 of storage period (Anon, 2008a).
Sensory characteristics of yogurt samples at the end of fermentation

Table 5 shows the sensory analysis of yogurts using score methodology. As shown, yogurts containing artichoke extract possessed weaker sensory acceptability for all sensory parameters compared to the controls. Artichoke extractin ABT-C yogurt exhibited more unpleasant flavor compared to ABY-C yogurt and had the lowest flavor score. Probably, Unsuitable bitter flavor of $\mathrm{ABY}-\mathrm{C}$ and $\mathrm{ABT}-\mathrm{C}$ yogurts was due to presence of sesquiterpene lactones (e.g. cynaropicrin) in artichoke extract (Lohr et al., 2009). Addition of artichoke extract into the yogurt changed the color of this product to yellowish. This characteristic was realized as an in appropriate sensory attribute (appearance) by the panelists. There were not considerable differences among the yogurt samples from non-oral texture points of view. However, differences were remarkable from oral texture standpoint. Yogurts containing artichoke extract had the lowest sensory score for oral texture. Generally, the highest total score was related to ABT yogurt whereas lowest total score belonged to ABT-C yogurt.

Table 5 Sensory analysis of the treatments using score methodology*

Parameters**

Treatments

$\begin{array}{llll}\text { Appearance } & \text { Flavor } & \text { Oral texture } & \text { Non-oral Texture score }\end{array}$

\begin{tabular}{|c|c|c|c|c|c|}
\hline ABY & $5.1^{\mathrm{abc}}$ & $16.7^{\mathrm{abc}}$ & $10.5^{\mathrm{a}}$ & $2.8^{\mathrm{abcd}}$ & $35.1^{\mathrm{ab}}$ \\
\hline ABY-C & $2.9^{\mathrm{d}}$ & $11.3^{\text {acd }}$ & $3.9^{\mathrm{cd}}$ & $2.0^{\mathrm{d}}$ & $20.1^{\mathrm{cd}}$ \\
\hline ABT & $6.7^{\mathrm{a}}$ & $17.3^{\mathrm{a}}$ & $10.1^{\mathrm{ab}}$ & $3.4^{\mathrm{a}}$ & $37.6^{\mathrm{a}}$ \\
\hline ABT-C & $4.0^{\mathrm{cd}}$ & $8.0^{\mathrm{d}}$ & $5.1^{\mathrm{c}}$ & $2.2^{\mathrm{cd}}$ & $19.3^{\mathrm{d}}$ \\
\hline
\end{tabular}

* Means shown with small letters represent significant differences $(p<0.05)$ in the same columns.

$* *$ Every data point is the mean of nine replications (nine panellists). 


\section{CONCLUSION}

Results of this study revealed that adding artichoke extract to $\mathrm{ABY}$ and $\mathrm{ABT}$ yogurts significantly increased viability of $L$. acidophilus LA-5 and B. lactis BB 12 at the end of fermentation as well as during refrigerated storage. Therefore, probiotic herbal yogurts are more functional from probiotic viability points of view.

Acknowledgement: The author as announced devotional thanks from Department of Food Science and Technology, Gorgan University of Agricultural Sciences and Natural Resources.

\section{REFERENCES}

KORBEKANDI H, MORTAZAVIAN AM, IRAVANI S. 2011. Stability and technology of probiotic in fermented milks: In: Probiotic and Prebiotic Foods: Technology, Stability and Benefits to the human health, (Shah N, ed.) Nova Science Publishing Ltd, USA. pp. 131-169

MORTAZAVIAN AM, KHOSROKHAVAR R, RASTGAR H, MORTAZAE GR. 2010. Effects of dry matter standardization order on biochemical and microbiological characteristics of Doogh (Iranian fermented milk drink). Ital J Food Sci. 1,98-104

SHAFIEE G, MORTAZAVIANAM, MOHAMMADIFAR MA, KOUSHKI MR, MOHAMMADI AR, MOHAMMADI R. 2010. Combined effects of drymatte content, incubation temperature and final $\mathrm{pH}$ of fermentation on biochemical and microbiological characteristics of probiotic fermented milk. Afr J Microbiol Res 4,1265-1274

TAMMIME AY, SAARELA M, KORSLUND SONDERGAARD A, MISTRY VV, SHAH NP. 2005. In: Probiotic Dairy Products, (Tamime, AY, ed) Blackwell Publishing Ltd, UK.

HEYDARI S, MORTAZAVIAN A M, EHSANI MR, MOHAMMADIFAR MA EZZATPANAH H, SOHRABVANDI S. 2011. Biochemical, microbiological and sensory characteristics of probiotic yogurt containing various prebiotic or fiber compounds. Ital J Food Sci. 23, 153-163

MORTAZAVIAN AM, EHSANI MR, MOUSAVI SM, REZAEI K SOHRABVANDI S, REINHEIMER JA. 2007a. Effect of refrigerated storage temperature on the viability of probiotic micro-organisms in yogurt. Int J Dairy Technol. 60, 123-127. http://dx.doi.org/10.1111/j.1471-0307.2007.00306 AHMADI E, MORTAZAVIAN AM, FAZELI MR, EZZATPANAH H MOHAMMADI R. 2012.The effects of inoculants variables on the physicochemical and organoleptic properties of Doogh. Int J Diary Technol.2, 274-281. http://dx.doi.org/10.1111/j.1471-0307.2011.00763

MORTAZAVIAN AM, EHSANI MR, AZIZI A, RAZAVI SH, MOUSAVI SM, SOHRABVANDI S. 2008.Viability of calcium alginate-microencapsulated probiotic bacteria in Iranian yogurt drink (Doogh) during the refrigerated storage period and under the simulated gastrointestinal conditions. Aust J Dairy Tech. 63 24-29

ANON: 2008a. Iran national standard for probiotic yogurt; No. 11325. Available on www.isiri.org [In Persian]

ANON: 2008b. Iran national standard for yogurt-Specifications and test methods ; No. 695. Available on www.isiri.org [In Persian]

MORTAZAVIAN AM, EHSANI MR, MOUSAVI SM, REINHEIMER JA, EMAMDJAME Z, SOHRABVANDI S, REZAEI K. 2006a. Preliminary investigation of the combined effect of heat treatment and incubation temperature on the viability of the probiotic micro-organisms in freshly made yogurt. Int $J$ Dairy Technol. 59, 8-11. http://dx.doi.org/10.1111/j.1471-0307.2006.00216 MORTAZAVIAN AM, SOHRABVANDI S, MOUSAVI SM, REINHEIMER JA. 2006b. Combined effects of temperature-related variables on the variables on the viability of probiotics in yogurt. Aus J Dairy Tech. 61, 248-252

MORTAZAVIAN AM, SOHRABVANDI S, REINHEIMER JA. 2007b. MRS bile agar: Its suitability for the enumeration of mixed Probiotic cultures in cultured dairy products. Milchwissenschaft. 62, 270-272

MORTAZAVIAN AM, GHORBANIPOUR S, MOHAMMADIFAR MA, MOHAMMADI M. 2011. Biochemical properties and viable probiotic population of yogurt at different bacterial inoculation rates and incubation temperatures. Philipp Agric Scientist. 94, 111-116

PARADA JL, CEIRE GZD, MULE MCZ, CANO MMS. 1998. Lactic acid bacteria growth pomoters from A. platensis. Int J Food Microbiol. 45, 225 228.http://dx.doi.org/10.1016/s0168-1605(98)00151-2

ZIELKE $\mathrm{H}$, KNEIFEL $\mathrm{H}$, WEBB LE, SOEDER CJ 1978. Stimulation of lactobacilli by an aqueous extract of the green alga Scenedesmus acutus 276-3a Eur J Appl Microbiol Biotechnol. 6, 79-86. http://dx.doi.org/10.1007/bf00500858 VARGA L, SZIGETI J, ÖRDOG V. 1999. Effect of a spirulina platensis biomass and that of its active components on single strains of dairy starter cultures. Milchwissenschaft. 54, 187-190

SOHRABVANDI S, MORTAZAVIAN AM, DOLATKHAH-NEJAD MR, BAHADORI MONFARED A. 2012. Suitability of MRS-bile agar for the selective enumeration of mixed probiotic bacteria in presence of mesophilic lactic acid cultures and yogurt bacteria. Iran J Biotechnol. 10, 16-21
GIBSON GR, ROBERFROID MB. 1995. Dietary modulation of the human colonic microbiota: introducing the concept of prebiotics. J Nutr. 125, 1041

KURITA H, TAJIMA O, FUKIMBARA T. 1979. Isolation and identification of nucleosides in Chlorella extract. J Agr Chem Soc Japan. 4, 131-133 http://dx.doi.org/10.1271/nogeikagaku1924.53.4 131

SHIROTA M, NAGAMATSU N, TAKECHI Y. 1964. Method for cultivating lactobacilli. US Patent. 3,123-128

STENGEL E. 1970. Anlagen und Verfahren der technis chen Algenmassen produktion. Ber Dtsch Bot Ges. 83,589-606

WEBB LE. 1982. Detection by Warburg manometry of compounds stimulatory to lactic acid bacteria. J Dairy Res. 49,479-486. http://dx.doi.org/10.1017/s0022029900022615

MOCANU D, ROTARU G, BOTEZ E, ANDRONOIU D \& NISTOR O. 2010 Probiotic yogurt with medicinal plants extract: Physical-chemical, microbiological and rheological characteristics. Journal of Agroalimentary Processes and Technologies. 16,469-476

LOPEZ-MOLINA D, NAVARRO-MARTNEZ MD, ROJAS-MELGAREJO F, HINER ANP, CHAZARRA S \& RODRIGUEZ-LOPEZ JN. 2005. Molecular properties and prebiotic effect of inulin obtained from artichoke (Cynara scolymus L.). Phytochemistry. 66,1476-1484.

http://dx.doi.org/10.1016/j.phytochem.2005.04.003

BONOMI A, BONOMI BM, 2001. L'impiegodella farina di foglie $\mathrm{d}$ carciofodisidratate (Cinara scolymus L.) nell'alimentazionedeivitelloni. Rivista Di Scienzadell-Alimentazione. 30,361-370

BIANCO VV, CIRULLI M. 1999. Carciofo. In: Fisionomia e profili di qualita dell'orticoltura meridionale. Consiglio Nazionale delle Ricerche.P.O. "Ricerca e SviluppoTecnologicoed Alta Formazione'’.94/99, 249-274.

LATTANZIO V, CARDINALI A, DI VENERE D, LINSALATA V \& PALMIERIS. 1994. Browning phenomen in stored artichoke (Cynara scolymus L.) heads: Enzymic or chemical reactions? FoodChemistry. 50, 1-7. http://dx.doi.org/10.1016/0308-8146(94)90083-3

GEBHARDT R, FAUSEL M. 1997. Antioxidant and hepatoprotective effects of artichoke extracts and constituents in cultured rat hepatocytes. Toxicology in Vitro. 11, 669-672.http://dx.doi.org/10.1016/s0887-2333(97)00078-7

JIMENEZ-ESCRING A, DRAGSTED LO, DANESHVAR B, PULIDO R, SAURA-CALIXTO F. 2003. In vitro antioxidant activities of edible artichoke (Cynara scolymus L.) and effect on biomarkers of antioxidants in rats. Journal of Agricultural and Food Chemistry 51, 5540 5545.http://dx.doi.org/10.1021/jf030047e

HOLST B, WILLIAMSON G. 2008. Nutrients and phytochemicals: from bioavailability to bioefficacy beyond antioxidants. Current Opinion in Biotechnology. 19, 73-82. http://dx.doi.org/10.1016/j.copbio.2008.03.003

KRAFT K. 1997. Artichoke leaf extract - Recent findings reflecting effects on lipid metabolism, liver and gastrointestinal tracts. Phytomedicine.4, 369-378 http://dx.doi.org/10.1016/s0944-7113(97)80049-9

KIRCHHOFF R, BECKERS C, KIRCHHOFF G, TRINCZEK-GARTNER H, PETROWICZ O, REIMANN HJ. 1994. Increase in choleresis by means of artichoke extract. Phytomedicine. 1, 107-115. http://dx.doi.org/10.1016/s0944 7113(11)80027-9

GEBHARDT R, FAUSEL M. 1997. Antioxidant and hepatoprotective effects of artichoke extracts and constituents in cultured rat hepatocytes. Toxicology In Vitro. 144, 279-286. http://dx.doi.org/10.1016/s0887-2333(97)00078-7

GEBHARDT R. 1995. Artichoke nextrakt: In vitro nachweis einer hemmwirkung auf die cholestrin-biosynthese. Med. Welt. 46, 348-350.

KRAFT K. 2001. Therapy of cardiovascular diseases with phytopharma-ceuticals - New findings from clinical studies with common hawthorn, artichoke leaf and garlic. BiologischeMedizin. 30, 56-60

MARDANI $\mathrm{V}$, ALAMI $\mathrm{M}$, ARABSHAHI DALOEE $\mathrm{S}$, SADEGHI MAHOONAK A, SOLEIMANI MH. 2011. Evaluation of antioxidant activity of Oenothera biennis extract and its effect on the oxidative stability of soybean oil Moorish. Twentieth Congress of Food Science and Technology, Iran. 20, 240p TAMIME A, BARRANTES E \& SWORD A. 1996. The effect of starch based fat substitutes on the microstructure of set-style yogurt made from reconstituted skimmed milk powder. International Journal of Dairy Technology. 49, 1-10. http://dx.doi.org/10.1111/j.1471-0307.1996.tb02612.x

APOSTOLIDIS E, KWON YI, SHETTY K. 2007. Inhibitory potential of herb fruit, and fungal enriched cheese against key enzymes linked to type 2 diabetes and hypertension. Innovative Food Science andEmerging Technologies. 8, 46-54. http://dx.doi.org/10.1016/j.ifset.2006.06.001

LATTANZIO V \& VAN SUMERE CF. 1987. Changes in phenolic compounds during the development and cold storage of artichoke (Cynara scolymus L.) heads. Food Chemistry. 24, 37-50. http://dx.doi.org/10.1016/0308 8146(87)90082-3

MOCANU GD, ROTARU G, BOTEZ E, VASILE A, GIITIN L, ANDRONOIU D, NISTOR O, VLASCEANU G \& DUNE A. 2009. Research concerning the production of a probiotic dairy product with added medicinal plant extracts. The Annals of the University „Dunarea de Jos” of Galați. Fascicle VI-Food Technology. XXXII. 37-44

AMIRDIVANI S \& BABA AS. 2011. Changes in yogurt fermentation characteristics, and antioxidant potential and in vitro inhibition of angiotensin- 
converting enzyme upon the inclusion of peppermint, dill and basil. LWT-Food

Science and Technology 44, 1458

1464. http://dx.doi.org/10.1016/j.lwt.2011.01.019

HARTE F, LUEDECK L, SWANSON B \& BARBOSA - CANOVAS GV

2005. Low - fat set yoghurt made from milk subjected to combinations of high hydrostatic pressure and thermal processing. Journal of Dairy Science. 75, 947 954

AMAYA-LIANO SL, MARTINEZ - ALGERIA AL, ZAZUETA - MORALES

JJ \& MARTINEZ - BUSTOS F. 2008. Acid thinned jicama and maize starches as fat substitute in stirred yogurt. LWT. 41, 1274-1281. http://dx.doi.org/10.1016/j.1wt.2007.08.012

ADWAN NL, ABDO ZMA \& HASSAN R. 2007. Effect of Feeding Artichoke Leaves Meal on Productive and Reproductive Performance of Mandarah Hens. International Journal of Poultry Science. 6, 826-834. http://dx.doi.org/10.3923/ijps.2007.826.834

GUSTAW W, KORDOWSKA-WIATER M \& KOZIOL J. 2011. The influence of selected prebiotics on the growth of lactic acid bacteria for bio-yoghurt production. Acta Scientiarum Polonorum: Technologia Alimentaria. 10, 455-466 DAMIN MR, ALCANTARA MR, NUNES AP \& OLIVEIRA MN. 2009. Effects of milk supplementation with skim milk powder, whey protein concentrate and sodium caseinate on acidification kinetics, rheological properties and structure of nonfat stirred yogurt. LWT - Food Science and Technology. 17, 1744-1750. http://dx.doi.org/10.1016/j.lwt.2009.03.019

SHAH NP. 2000. Effect of milk-derived bioactives: an overview. British Journal ofNutrition. 84, 3-10. http://dx.doi.org/10.1017/s000711450000218x

NICHIFORESCU EA. 1970. Composition of caffeoylquinic acid derivatives of artichoke (Cynara scolymus L.). Plant Med Phytother. 4, 56-62.

ADZET T and PUIGMACIA M. 1985. High-performance liquid chromatography of caffeoylquinic acid derivatives of Cynara scolymus L. leaves. J Chromatogr A. 348, 447-453. http://dx.doi.org/10.1016/s0021-9673(01)92486-0

DRANIK LI, DOLGANENKO LG, SLAPKE J, and THOMA N. 1996. Chemical composition and medical usage of Cynara scolymus L. Rastit Resur. 32, 98-104

WAGENBRETH D. 1996. Evaluation of artichoke cultivars for growing and pharmaceutical use. Beitr Zuchtungs forsch . 2, 400-403

THOMPSON JL, LOPETCHARAT K \& DRAKE MA. 2007. Preferences for commercial strawberry drinkable yogurts among African American, Caucasian, and Hispanic consumers in the United States. Journal Dairy Science. 90, 49744987. http://dx.doi.org/10.3168/jds.2007-0313

GEBHARDT R. 1997. Antioxidative and protective properties of extracts from leaves of the artichoke (Cynara scolymus L.) against hydroperoxide-induced oxidative stress in cultured rat hepatocytes. Toxicology and Applied Pharmacology. 144, 279-286. http://dx.doi.org/10.1006/taap.1997.8130

BROWN JE \& RICE-EVANS CA. 1998. Luteolin-rich artichoke extracts protects low density lipoproteins from oxidation in vitro. Free Radical Research. 29, 247-255. http://dx.doi.org/10.1080/10715769800300281

LUTZ M, HENRIQUEZ C \& ESCOBAR M. 2011. Chemical composition and antioxidant properties of mature and baby artichokes (Cynara scolymus L.), raw and cooked. Journal of Food Composition and Analysi. 24, 49-54

LLORACH REJ, TOMAS-BARBERRAN F, FERRERES F. 2002. Artichoke (Cynara scolymus L.) by products as a potential source of health-promoting antioxidant phenolics. Journal of Agricultural and Food Chemistry. 50, 34583464. http://dx.doi.org/10.1021/jf0200570

FRATIANNI F, TUCCI M, De PALMA M, PEPE R, NAZZARO F. 2007. Polyphenolic composition in different parts of some cultivars of globe artichoke (Cynara cardunculus L. var. scolymus (L.) Fiori). Food Chemistry. 104, 1282 1286.http://dx.doi.org/10.1016/j.foodchem.2007.01.044

MOCANU, GD, BOTEZ E, NISTOR OV \& ANDRONOIU DG. 2011 Characterization of probiotic yoghurt obtained with medicinal plant extracts and modelling of bacteria cell growth during its production. Journal of Agroalimentary Processes and Technologies. 17, 65-71

LOHR G, DETERS A\& HENSEL A. 2009. In vitro investigations of Cynara scolymus L. extracton cell physiology of HepG2 liver cells. Brazilian Journal of Pharmaceutical Sciences. 45, 201-208 